\title{
Potensi Bawang Putih (Alium sativum) dan Lactobacillus acidophilus sebagai Sinbiotik untuk Meningkatkan Performans Ayam Broiler
}

\author{
The Potency of Garlic (Allium sativum) and Lactobacillus acidophilus as Synbiotics on \\ Broiler Performance
}

\section{T. Puspitaningrum*, L. D. Mahfudz, dan M. H. Nasoetion}

\author{
Fakultas Peternakan dan Pertanian Universitas Diponegoro \\ Jl. Prof. Soedarto No.13, Tembalang, Kec. Tembalang, Kota Semarang, Jawa Tengah 50275 \\ *Corresponding e-mail:lmahfudz@gmail.com
}

\begin{abstract}
This study was aimed to examinated the use of combination of extract garlic (Alium sativum) with Lactobacillus acidophilus as symbiotic to improve the performance of broiler chickens. The experiment was conducted using

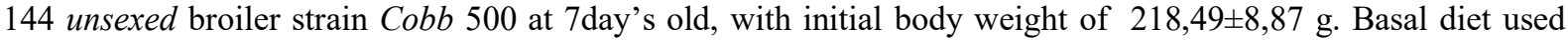
were consists of corn, fish meal, soybean meal, bran, and premix. The design used completely randomized design (CRD) with 3 treatments and 8 replications. Each experimental units consisted of 6 broilers. Data were analyzed with analysis of variance (ANOVA) with $\mathrm{F}$ test to known effect of treatments. If there is a significant effect of treatments, followed by Duncan's multiple range test. The treatments were $\mathrm{T} 0=$ (basal feed), $\mathrm{T} 1=($ basal feed +2 $\mathrm{ml} / \mathrm{kg}$ synbiotic), $\mathrm{T} 2=$ (basal feed $+4 \mathrm{ml} / \mathrm{kg}$ synbiotic). The parameters were; feed intake, body weight gain, and feed conversion ratio. The results showed that the addition of synbiotic $(4 \mathrm{ml} / \mathrm{kg}$ ransum/T2) increased $(\mathrm{P}<0,05)$ feed intake and body weight gain, while conversion feed ratio decreased. It can be concluded that the addition of synbiotic $4 \mathrm{ml} / \mathrm{kg}$ diet (T2) increased broilers performance of broiler chicken.
\end{abstract}

Key words: broilers chicken, garlic, Lactobacillus acidophilus, performance

\begin{abstract}
ABSTRAK
Penelitian ini bertujuan untuk mengkaji penggunaan kombinasi ekstrak bawang putih (Alium sativum) dengan Lactobacillus acidophilus sebagai sinbiotik yang diberikan pada ayam broiler untuk meningkatkan performans ayam broiler. Percobaan dilakukan menggunakan 144 ekor ayam broiler unsexed strain Cobb 500, umur 7 hari

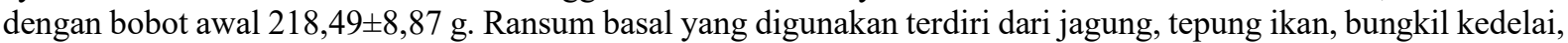
dedak, dan premix. Rancangan yang digunakan rancangan acak lengkap (RAL) dengan 3 perlakuan dan 8 ulangan. Setiap unit percobaan terdiri dari 6 ekor ayam broiler. Data dianalisis ragam (ANOVA) dengan uji $F$ untuk mengetahui pengaruh perlakuan. Apabila terdapat pengaruh perlakuan nyata dilanjutkan uji berjarak Duncan. Perlakuan yang diberikan yaitu $\mathrm{T} 0=($ ransum basal $), \mathrm{T} 1=($ ransum basal $+\operatorname{sinbiotik} 2 \mathrm{ml} / \mathrm{kg}), \mathrm{T} 2=(\mathrm{ransum}$ basal + sinbiotik $4 \mathrm{ml} / \mathrm{kg}$. Parameter yaitu; konsumsi ransum, pertambahan bobot badan (PBB), dan konversi ransum. Hasil penelitian menunjukkan bahwa penambahan $4 \mathrm{ml}$ sinbiotik (T2) kombinasi bawang putih (Alium sativum) dan Lactobacillus acidophilus dalam ransum dapat meningkatkan konsumsi ransum dan PBB, sementara konversi ransum semakin menurun $(\mathrm{P}<0,05)$. Dapat disimpulkan bahwa penambahan $4 \mathrm{ml}(\mathrm{T} 2)$ sinbiotik dari kombinasi ekstrak bawang putih dan Lactobacillus acidophilus meningkatkan performans ayam broiler.
\end{abstract}

Kata kunci : ayam broiler, bawang putih, Lactobacillus acidophilus, performans

\section{PENDAHULUAN}

Ayam broiler memiliki pertumbuhan cepat, umur panen singkat dan efisien merubah pakan menjadi daging. Ayam broiler memiliki kelemahan yaitu immunitasnya rendah, sehingga sangat rentan terhadap penyakit. Upaya yang dilakukan peternak yaitu dengan penggunaan antibiotic growth promotor (AGP) yang dapat mencegah penyakit dan meningkatkan pertumbuhan ternak. Namun penggunaan penambahan AGP terus - menerus dapat berakibat buruk pada ayam broiler, dan adanya residu yang berbahaya dalam daging. Maka para peneliti mencoba alternatif mengganti AGP dengan penggunaan sinbiotik, yaitu kombinasi antara probiotik dan prebiotik.

Sinbiotik diharapkan dapat meningkatkan populasi bakteri non patogen dan menekan bakteri patogen dalam saluran pencernaan. Keuntungan dari sinbiotik adalah meningkatkan daya tahan hidup bakteri probiotik karena tersedianya substrat untuk fermentasi, sehingga ternak mendapat manfaat yang lebih baik dari kombinasi tersebut (Purba et al., 2016). 
Probiotik adalah mikroorganisme hidup yang dapat menguntungkan dengan menjaga keseimbangan mikroflora usus di saluran pencernaan. Mikroba yang sering digunakan sebagai probiotik adalah Lactobacillus acidophilus mempunyai kemampuan merombak karbohidrat sederhana menjadi asam laktat. Seiring dengan meningkatnya asam laktat, maka pH lingkungan menjadi rendah dan menyebabkan mikroba patogen tidak dapat berkembang (Astuti et al., 2015)

Bawang putih dapat mengoptimalkan fungsi metabolisme, sehingga meningkatkan efisiensi dalam penggunaan ransum. Bawang putih mengandung fitobiotik yaitu alisin. Alisin bersifat bakteriostatik. Alisin mampu menembus dinding sel bakteri sehingga sel bakteri menjadi rusak dan mati. Meskipun bawang putih mengandung fitobiotik, tetapi bawang putih dapat digunakan sebagai nutrisi Lactobacillus acidophilus, karena bakteri ini tahan terhadap alisin. Lactobacillus acidophilus dapat dijadikan probiotik apabila dikombinasikan dengan bawang putih, karena Lactobacillus acidophilus juga dapat memanfaatkan fruktosa dari bawang putih. Prebiotik adalah bahan pakan yang tidak dapat dicerna oleh ternak unggas, meningkatkan bakteri non patogen sehingga menguntungkan ternak dan tidak mengakibatkan residu pada tubuh ternak (Hartono et al., 2016).

Bawang putih mengandung fruktosa oligosakarida (FOS) sebanyak 3,34\% sehingga dapat dijadikan sebagai prebiotik. Fruktosa oligosakarida yang dikenal sebagai prebiotik, sehingga menjadi nutrisi bagi probiotik (Sunu et al., 2019). Bawang putih memiliki kandungan senyawa inulin sebesar 9-16\%. Inulin dapat digunakan sebagai substrat atau prebiotik karena juga termasuk fruktooligosakarida yang tidak dapat dihidrolisis enzim pencernaan tetapi merupakan sumber nutrisi oleh bakteri non patogen usus halus, sehingga dapat untuk meningkatkan pertumbuhan ayam broiler (Nurhalimah, 2018).

\section{MATERI DAN METODE}

Materi yang digunakan pada penelitian yaitu 144 ekor unsexed ayam broiler strain Cobb 500 umur 7 hari dengan bobot $218,49 \pm 8,87 \mathrm{~g}$, ransum basal, serta sinbiotik dari prebiotik bawang putih (Alium sativum) dengan probiotik Lactobacillus acidophilus. Proses pembuatan dari sinbiotik tersebut yaitu, bawang putih yang telah dipersiapkan sebanyak $3 \mathrm{~kg}$ kemudian dibersihkan dan dikupas terlebih dahulu. Setelah dikupas, bawang putih dicuci dan diiris dengan ketebalan 1 $\mathrm{cm}$. Potongan bawang putih dimasukkan ke dalam juicer untuk diambil ekstrak bawang putih. Ekstrak kemudian disaring dan disterilkan dengan metode pasteurisasi selama 10 menit. Ekstrak disimpan dalam wadah dan diletakkan di tempat tertutup pada suhu dibawah $20^{\circ} \mathrm{C}$.

Ekstrak bawang putih dicampur bakteri Lactobacillus acidophilus dengan rasio $100 \mathrm{ml}$ banding $1 \mathrm{ml}$. Isolat dari media MRS gliserol $20 \%$, kultur bakteri diremajakan pada media MRS agar di inkubasi pada suhu $37^{\circ} \mathrm{C}$ selama $24-48$ jam untuk mengaktifkan bakteri. Tahap selanjutnya diinokulasikan pada media MRS broth sebanyak 1 oose dan diinkubasi pada suhu $37^{\circ} \mathrm{C}$ selama 24 jam.

Ransum basal yang disusun terdiri dari jagung, dedak, bungkil kedelai, tepung ikan, premix, tertera pada Tabel 1. Alat yang digunakan adalah tempat minum, tempat pakan, timbangan analitik, timbangan digital, spryer desinfektan, ember, nampan, termohygro meter, gunting dan pisau.

Tabel 1. Komposisi Nutrien Ransum Ayam Broiler

\begin{tabular}{lc}
\hline \multicolumn{1}{c}{ Bahan Pakan } & $\begin{array}{c}\text { Komposisi } \\
\text { Ransum (\%) }\end{array}$ \\
\hline Jagung & 51,50 \\
Dedak & 15,00 \\
Bungkil Kedelai & 23,00 \\
Tepung Ikan & 10,00 \\
Premiks & 0,50 \\
Total & $\mathbf{1 0 0 , 0 0}$ \\
\hline Kandungan Nutrisi : & \\
EM (kkal/kg) & $3.051,00$ \\
Protein kasar (\%) & 22,01 \\
Lemak kasar (\%) & 6,20 \\
Serat kasar (\%) & 4,36 \\
Calsium (Ca) & 1,99 \\
Fosfor (P) & 1,08 \\
Arginin (\%) & 1,29 \\
Methionin (\%) & 0,49 \\
Lisin (\%) & 1,21 \\
\hline Perhitungan ransum berdasarkan hasil analisis \\
proksimat Laboratorium Ilmu Nutrisi dan Pakan, \\
Fakultas Peternakan dan Pertanian Universitas \\
Diponegoro, Semarang
\end{tabular}

Penelitian pengaruh penambahan sinbiotik bawang putih (Alium sativum) dengan bakteri Lactobacillus acidophilus sebagai aditif pakan terhadap performa ayam broiler (konsumsi 
ransum, pertambahan bobot badan, dan konversi ransum) dengan menggunakan Rancangan Acak Lengkap (RAL) dengan 3 perlakuan dan 8 ulangan.

Perlakuan yang diberikan: T0: ransum basal; T1: ransum basal + sinbiotik $2 \mathrm{ml} / \mathrm{kg}$; T2: ransum basal + sinbiotik $4 \mathrm{ml} / \mathrm{kg}$. Persiapan kandang sebelum pemeliharaan, kandang ayam dilakukan proses sanitasi, pengapuran, kemudian disemprot formalin dan dibiarkan selama 3 hari. Ternak yang digunakan dalam penelitian menggunakan ayam broiler unsexseed umur 7 hari. Penelitian dilakukan selama 35 hari. Umur 1 - 7 hari dengan pemberian pakan komersial dan pada umur $7-42$ diberi ransum dengan penambahan sinbiotik bawang putih (Alium sativum) dan Lactobacillus acidophilus. Pemberian air minum secara ad libitum sehari 2 kali yaitu pagi dan sore.

Konsumsi pakan dicatat setiap hari diperoleh dengan dicatat jumlah ransum yang dikonsumsi dikurangi dengan sisa ransum. Pertambahan bobot badan diperoleh dari penimbangan bobot badan ayam. Proses penimbangan dilakukan setiap minggu untuk melihat pertumbuhan pada ayam dengan menggunakan timbangan. Kemudian melakukan perhitungan dengan cara bobot badan akhir dikurangi bobot badan awal.. Konversi Ransum diperoleh dari jumlah konsumsi ransum sampai akhir minggu, dibagi dengan pertambahan bobot badan

Model linier yang menjelaskan nilai setiap pengamatan untuk RAL adalah:

$\mathrm{Y}_{\mathrm{ij}}=\mu+\tau_{\mathrm{i}}+\varepsilon_{\mathrm{ij}}$

Keterangan :

$\mathrm{Y}_{\mathrm{i}}=$ Hasil pengamatan pengaruh perlakuan dosis dosis kombinasi Lactobacillus acidophilus dan bawang putih ke-i dan ulangan ke-j $\mu=$ Nilai rata - rata umum

$\tau_{\mathrm{i}}=$ Pengaruh perlakuan dosis dosis kombinasi Lactobacillus acidophilus dan bawang putih ke-i

$\varepsilon_{\mathrm{ij}}=$ Galat percobaan akibat perlakuan dosis kombinasi Lactobacillus acidophilus dan bawang putih ke-i dan ulangan ke-j

\section{HASIL DAN PEMBAHASAN}

\section{Konsumsi ransum}

Hasil penelitian menunjukan hasil konsumsi ransum pada penambahan kombinasi bawang putih (Alium sativum) dan Lactobacillus acidophilus tercantum pada Tabel 2.

Rata rata konsumsi ransum pada ayam broiler selama 42 hari pemeliharaan sekitar 2.909 $-2.682 \mathrm{~kg}$ /ekor (Tabel 2). Konsumsi ayam broiler umur 14-21 hari tidak dipengaruhi $(\mathrm{P}>0,05)$ oleh kombinasi bawang putih dan Lactobacillus acidophilus. Konsumsi ransum pada ayam broiler umur 28 - 35 hari dan rata - rata konsumsi ransum 14 - 42 hari dengan penambahan sinbiotik dengan taraf $0,4 \% \quad(\mathrm{~T} 2) \quad$ lebih tinggi $\quad(\mathrm{P}<0,05)$ dibandingkan taraf $0,2 \%$ (T1) tanpa penambahan sinbiotik (T0). Penambahan kombinasi bawang putih dengan Lactobacillus acidophilus efektif meningkatkan konsumsi ransum ayam broiler pada umur 28 - 35 hari nyata meningkatkan terhadap rata - rata konsumsi ransum ayam broiler selama 42 hari $(\mathrm{P} \leq 0,05)$. Pada penelitian Dharmawati et al. (2013) menyatakan penambahan tepung bawang putih dengan taraf pemberian $0,25 \%$ pada ayam broiler selama 35 hari belum mempengaruhi $(\mathrm{P}>0,05)$ konsumsi ransum ayam broiler. Pada penelitian Astuti et al., (2015) pemberian probiotik cair Lactobacillus $s p$. pada pakan dengan taraf pemberian $0,6 \%$ ayam broiler selama 35 hari nyata $(\mathrm{P}<0,01)$ meningkatkan konsumsi ransum ayam broiler.

Tabel 2. Hasil pemberian penambahan sinbiotik terhadap konsumsi ransum setiap minggu

\begin{tabular}{|c|c|c|c|}
\hline \multirow{2}{*}{ Umur (hari) } & T0 & \multirow{2}{*}{\multicolumn{2}{|c|}{$\begin{array}{c}\mathrm{T} 1 \\
\text { kg/ekor } \ldots \ldots \ldots \ldots \ldots \ldots \ldots \ldots \ldots \ldots\end{array}$}} \\
\hline & & & \\
\hline 14 & $1,557 \pm 0,065^{\mathrm{a}}$ & $1,608 \pm 0,098^{a}$ & $1,625 \pm 0,036^{\mathrm{a}}$ \\
\hline 21 & $2,110 \pm 0,070^{a}$ & $2,092 \pm 0,045^{\mathrm{a}}$ & $2,102 \pm 0,008^{a}$ \\
\hline 28 & $2,430 \pm 0,189^{b}$ & $2,643 \pm 0,341^{a b}$ & $2,692 \pm 0,052^{a}$ \\
\hline 35 & $4,011 \pm 0,210^{b}$ & $4,182 \pm 0,152^{b}$ & $4,538 \pm 0,186^{\mathrm{a}}$ \\
\hline 42 & $3,304 \pm 0,309^{a}$ & $3,463 \pm 0,479^{\mathrm{a}}$ & $3,588 \pm 0,063^{a}$ \\
\hline Rata - rata & $2,682 \pm 0,080^{\mathrm{c}}$ & $2,798 \pm 0,136^{b}$ & $2,909 \pm 0,035^{\mathrm{a}}$ \\
\hline
\end{tabular}

Superskrip yang berbeda menunjukkan perbedaan nyata $(\mathrm{P}<0,05)$ 
Konsumsi ransum yang meningkat disebabkan bakteri asam laktat pada ransum dapat meningkatkan aktivitas enzimatis dan membantu pencernaan, sehingga menyebabkan penyerapan zat makanan lebih cepat dan saluran pencernaan lebih cepat kosong sehingga ayam broiler lebih cepat lapar. Menurut Surono (2004) bakteri asam laktat dapat meningkatkan proses sekresi dari enzim pencernaan seperti enzim pepsin yang dapat menghidrolisis protein, sehingga protein lebih mudah diserap oleh tubuh.

\section{Pertambahan bobot badan}

Berdasarkan data pada Tabel 3 dapat diketahui rata rata pertambahan bobot badan pada ayam broiler sampai masa pemeliharaan 42 hari setiap minggu sebesar $0,317-0,376 \mathrm{~kg} / \mathrm{ekor}$.

Tabel 3. Hasil pemberian penambahan sinbiotik terhadap pertumbuhan bobot badan setiap minggu

\begin{tabular}{cccc}
\hline \multirow{2}{*}{ Umur (hari) } & 0 & $\mathrm{~T} 1$ & $\mathrm{~T} 2$ \\
\cline { 2 - 4 } & & $\mathrm{kg} / \mathrm{ekor}$ & \\
\hline 14 & $0,221 \pm 0,015^{\mathrm{b}}$ & $0,222 \pm 0,012^{\mathrm{b}}$ & $0,245 \pm 0,008^{\mathrm{a}}$ \\
21 & $0,278 \pm 0,024^{\mathrm{a}}$ & $0,293 \pm 0,056^{\mathrm{a}}$ & $0,308 \pm 0,014^{\mathrm{a}}$ \\
28 & $0,379 \pm 0,055^{\mathrm{a}}$ & $0,365 \pm 0,031^{\mathrm{a}}$ & $0,353 \pm 0,029^{\mathrm{a}}$ \\
35 & $0,366 \pm 0,052^{\mathrm{b}}$ & $0,444 \pm 0,053^{\mathrm{a}}$ & $0,433 \pm 0,072^{\mathrm{a}}$ \\
42 & $0,346 \pm 0,089^{\mathrm{b}}$ & $0,367 \pm 0,036^{\mathrm{b}}$ & $0,545 \pm 0,066^{\mathrm{a}}$ \\
Rata - rata & $0,318 \pm 0,080^{\mathrm{c}}$ & $0,338 \pm 0,085^{\mathrm{b}}$ & $0,377 \pm 0,114^{\mathrm{a}}$ \\
\hline
\end{tabular}

Superskrip yang berbeda menunjukkan perbedaan nyata $(\mathrm{P}<0,05)$

Berdasarkan data pada Tabel 3 dapat diketahui rata - rata pertambahan bobot badan pada ayam broiler sampai masa pemeliharaan 42 hari setiap minggunya sekitar $0,318-0,377$ kg/ekor. Penambahan bawang putih dan Lactobacillus acidophilus pada ransum ayam meningkatkan $(\mathrm{P}>0,05)$ rata - rata pertambahan bobot badan selama 42 hari. Menurut Dharmawati et al. (2013) penambahan tepung bawang putih pada pakan dengan level tertinggi $0,25 \%$ sampai umur 35 hari tidak berpengaruh nyata $(\mathrm{P}>0,05)$ terhadap pertambahan bobot badan ayam dan bobot akhir ayam

\section{Konversi ransum}

Hasil penelitian menunjukkan hasil konversi ransum pada penambahan kombinasi bawang putih (Alium sativum) dan Lactobacillus acidophilus terdapat pada Tabel 4.

Tabel 4. Hasil pemberian penambahan sinbiotik terhadap konversi ransum setiap minggu

\begin{tabular}{cccc}
\hline Umur (hari) & T0 & T1 & T2 \\
\cline { 2 - 4 } & & $\mathrm{kg} / \mathrm{ekor}$ & $1,112 \pm 0,030^{\mathrm{b}}$ \\
\hline 14 & $1,215 \pm 0,060^{\mathrm{a}}$ & $1,169 \pm 0,040^{\mathrm{a}}$ & $1,139 \pm 0,050^{\mathrm{b}}$ \\
21 & $1,244 \pm 0,093^{\mathrm{a}}$ & $1,170 \pm 0,105^{\mathrm{ab}}$ & $1,099 \pm 0,086^{\mathrm{b}}$ \\
28 & $1,229 \pm 0,160^{\mathrm{a}}$ & $1,196 \pm 0,152^{\mathrm{a}}$ & $0,874 \pm 0,197^{\mathrm{b}}$ \\
35 & $1,187 \pm 0,161^{\mathrm{a}}$ & $1,068 \pm 0,051^{\mathrm{a}}$ & $1,988 \pm 0,209^{\mathrm{b}}$ \\
42 & $2,512 \pm 0,340^{\mathrm{a}}$ & $2,337 \pm 0.277^{\mathrm{a}}$ & $1,243 \pm 0,036^{\mathrm{c}}$ \\
\hline
\end{tabular}

Superskrip yang berbeda menunjukkan perbedaan nyata $(\mathrm{P}<0,05)$

Hasil konversi ransum pada Tabel 4 menunjukan selama 42 hari berkisar antara 1,477$1,243 \mathrm{~kg} /$ ekor. Penambahan kombinasi bawang putih dan Lactobacillus acidophilus pada ransum selama 42 hari menurunkan $(\mathrm{P} \leq 0,05)$ konversi ransum. Hasil konversi terbaik terdapat pada taraf $0,4 \%$ dengan rata-rata nilai konversi 1,243 $\mathrm{kg} /$ ekor. Hasil penelitian Dharmawati et al. (2013) menunjukkan penambahan tepung bawang putih dengan taraf pemberian $0,25 \%$ pada ayam broiler selama 35 hari dapat menurunkan $(\mathrm{P} \leq 0,05)$ nilai konversi ransum dengan hasil antara 1,63-1,53.

Bawang putih mengoptimalkan fungsi metabolisme pada tubuh ayam broiler sehingga penggunaan ransum lebih efisien. Ambarwati dan Syah (2018) menyatakan bawang putih selain memiliki kandungan vitamin dan mineral, juga mempunyai senyawa aktif seperti alisin. Senyawa alisin bersifat anti bakteri sehingga mampu menghambat hingga membunuh pertumbuhan bakteri patogen, sehingga metabolisme tubuh 
ayam broiler lebih baik, penyerapan zat makanan lebih baik yang menyebabkan konversi ransum menurun dan pertambahan bobot badan meningkat. Satriawan (2016) menambahkan nilai konversi ransum yang kecil lebih ekonomis disebabkan dengan pemberian ransum yang sedikit sudah dapat meningkatkan bobot badan.

\section{KESIMPULAN}

Berdasarkan hasil penelitian dapat disimpulkan pemberian kombinasi bawang putih (Alium sativum) dan Lactobacillus acidophilus efektif meningkatkan performans ayam broiler.

\section{DAFTAR PUSTAKA}

Astuti, F.K., Busono. W dan O. Sofjan. 2015. Pengaruh pengaruh penambahan probiotik cair dalam pakan terhadap penampilan produksi pada ayam pedaging. J. Pembangunan dan Alam Lestari 6 (2): 99 104.

Ambarwati, L., dan S. P. Syah. 2018. Penambahan tepung bawang putih (Allium sativun) sebagai feed additve herbal pada ransum terhadap kadar kolesterol darah dan performans ayam broiler. Prosiding Seminar Teknologi dan Agribisnis Peternakan VI: Pengembangan Sumber Daya Genetik Ternak Lokal 223 - 230

Dharmawati, S., N. Firahmi, dan Parwanto. 2013. Penambahan tepung bawang putih (allium sativum 1) sebagai feed aditif dalam ransum terhadap penampilan ayam pedaging. Majalah Ilmiah Pertanian Ziraa'ah 38(3): 17-22.
Hartono, E.F., N. Iriyanti, dan S. Suhermiyati. 2016. Efek penggunaan sinbiotik terhadap kondisi miklofora dan histologi usus ayam sentul jantan. Agripet 16(2):97-105

Kurniawan, L. A., U. Atmomarsono dan L. D. Mahfudz. 2012. Pengaruh berbagai frekuensi pemberian pakan dan pembatasan pakan terhadap pertumbuhan. Agromedia 30(2): 15-22

Nurhalimah, S. 2018. Pengaruh prebiotik ekstrak etanol umbi bawang putih pada pertumbuhan bakteri probiotik Lactobacillus casei secara in vitro. Fakultas Matematika dan Ilmu Pengetahuan Alam. Universitas Jember. Skripsi.

Purba, G.S., T. E. W. Widyastutia., dan I. Kuswardani. 2016. Pengaruh konsentrasi tepung pepaya dan lama penyimpanan terhadap sifat fisik beads dan viabilitas lactobacillus acidophilus fncc 0051 terimobil. Jurnal Teknologi Pangan dan Gizi 15 (2): 79-86.

Satriawan, S. A. 2016. Pengaruh probiotik dan herbal terhadap rasio konversi pakan pada ayam pedaging. Fakultas Kedokteran Hewan. Universitas Airlangga. Surabaya. Skripsi.

Sunu, P., D. Sunarti., L. D. Mahfudz, dan V. D. Yunianto. 2019. Prebiotic activity of garlic (Allium sativum) extract on Lactobacillus acidophilus. Vetenary World 12(12): 20462051. 